\title{
Shallow landslide's stochastic risk modelling based on the precipitation event of August 2005 in Switzerland: results and implications
}

\author{
P. Nicolet ${ }^{1}$, L. Foresti ${ }^{1,2}$, O. Caspar ${ }^{1}$, and M. Jaboyedoff ${ }^{1}$ \\ ${ }^{1}$ Center of Research on Terrestrial Environment, University of Lausanne, Lausanne, Switzerland \\ ${ }^{2}$ Royal Meteorological Institute of Belgium, Brussels, Belgium \\ Correspondence to: P. Nicolet (pierrick.nicolet@unil.ch)
}

Received: 28 February 2013 - Published in Nat. Hazards Earth Syst. Sci. Discuss.: 28 March 2013

Revised: 29 August 2013 - Accepted: 29 October 2013 - Published: 9 December 2013

\begin{abstract}
Due to their relatively unpredictable characteristics, shallow landslides represent a risk for human infrastructures. Multiple shallow landslides can be triggered by widespread intense precipitation events. The event of August 2005 in Switzerland is used in order to propose a risk model to predict the expected number of landslides based on the precipitation amounts and lithological units. The spatial distribution of rainfall is characterized by merging data coming from operational weather radars and a dense network of rain gauges with an artificial neural network. Lithologies are grouped into four main units, with similar characteristics. Then, from a landslide inventory containing more than 5000 landslides, a probabilistic relation linking the precipitation amount and the lithology to the number of landslides in a $1 \mathrm{~km}^{2}$ cell, is derived. In a next step, this relation is used to randomly redistribute the landslides using Monte Carlo simulations. The probability for a landslide to reach a building is assessed using stochastic geometry and the damage cost is assessed from the estimated mean damage cost using an exponential distribution to account for the variability. Although the model reproduces well the number of landslides, the number of affected buildings is underestimated. This seems to result from the human influence on landslide occurrence. Such a model might be useful to characterize the risk resulting from shallow landslides and its variability.
\end{abstract}

\section{Introduction}

Shallow landslides often represent a risk for housing, people and infrastructures. Compared with deep-seated landslides, shallow landslides usually trigger spontaneously, flow at higher speed and are not likely to affect repeatedly the same location due to the changes in soil stability conditions (e.g. van Westen et al., 2006; Corominas and Moya, 2008). Consequently, most research efforts focus on the prediction of their exact location and, less frequently, their timing. Several methods for the mapping of landslide susceptibility exist and are based on physical models (e.g. Pack et al., 1998; Montgomery and Dietrich, 1994; Godt et al., 2008) or statistical approaches (e.g. Carrara et al., 1991). Since rainfall has been recognized as being a frequent triggering mechanism (e.g. Wieczorek, 1996), many authors, following Campbell (1975) and Caine (1980), proposed early-warning systems based upon criteria of precipitation intensity and duration (e.g. Guzzetti et al., 2008). Other studies also use the antecedent precipitation as a proxy for considering the groundwater level preceding the precipitation event (Crozier, 1999; Glade et al., 2000). More direct approaches are based upon the real-time monitoring of soil moisture (Matsushi and Matsukura, 2007; Baum and Godt, 2010) or the use of transfer functions to estimate the soil water content from precipitation measurements (Cascini and Versace, 1988; Capparelli and Versace, 2011; Greco et al., 2013).

Many rainfall-induced large landslide events have been recognized worldwide, for example in Italy (Crosta, 1998; Crosta and Frattini, 2003; Crosta and Dal Negro, 2003; Cardinali et al., 2006; Gullà et al., 
2008), Spain (Corominas and Moya, 1999), the USA (Campbell, 1975; Whittaker and McShane, 2012), New Zealand (Crozier et al., 1980; Glade, 1998; Crozier, 2005), Taiwan (Yu et al., 2006), the Portuguese island of Madeira (Nguyen et al., 2013) and in Switzerland (Bollinger et al., 2000).

Despite the numerous contributions to the physical understanding of the phenomenon itself (for a broad reference list, although not up to date, see De Vita et al., 1998), studies on the assessment of landslide risk are less commonly found in the literature. Examples of quantitative risk analysis (QRA) at regional scale can be found in Cardinali et al. (2002), Remondo et al. (2005) and Catani et al. (2005). However, these studies provide a mean annual risk with no information on the expected distribution of annual costs. More recently, applications of regional-scale QRA providing exceedance probabilities were presented in Jaiswal et al. (2011) and Ghosh et al. (2012). Although most of the QRA methodologies are developed for local or regional scales, some of them, for example Catani et al. (2005), might be generalized to a larger area.

Switzerland was affected in August 2005 by a rainfall event with measured precipitation reaching $324 \mathrm{~mm}$ in 6 days. Although floods were the main cause of damage, more than 5000 landslides were reported (Raetzo and Rickli, 2007). Landslide-induced damage has been estimated by Hilker et al. (2007) at CHF 92 million (USD 99 million; debris-flows not included) and represents $4.5 \%$ of the total damage cost.

As already mentioned by Jaboyedoff and Bonnard (2007) and by Rickli et al. (2008), landslide density was highly correlated with the total precipitation amount. Following their ideas, this article proposes a risk model for shallow landslides based on the event of August 2005. The input parameters of the model include a rainfall and a lithological map. The map of 6 day rainfall accumulations is constructed by interpolating a high resolution rain gauge network using weather radar data as external drift. A geotechnical map is interpreted in order to group different units into 4 main lithological settings. The expected number of landslides is predicted as a function of rainfall level conditional to the lithological type. A geometrical probability concept is then employed to predict the potential number of landslides affecting buildings and the corresponding damage cost.

The paper is structured as follows. Section 2 details the rainfall event of August 2005 in Switzerland both from a meteorological and lithological viewpoint. Section 3 explains the methodology to assess the landslide probability as a function of rainfall accumulation and lithological context. Section 4 presents the risk analysis results in terms of expected number of landslides, number of affected buildings and associated cost. Finally, Sects. 5 and 6 discuss and conclude the paper.

\section{The rainfall event of August 2005 in Switzerland}

\subsection{Study area}

The study area covers the entire Swiss territory (around $42000 \mathrm{~km}^{2}$ ), which extends from the Jura Mountains in the northwest, to the Alps, in the southeast, through the Molassic Plateau, where most of the population is concentrated. Special attention is given to the location where most of the landslides occurred, which is the central part of Switzerland, between the cities of Bern and Lucerne (Fig. 1). Landslides occurred in the tectonic units described below (Trümpy, 1980; University of Bern and FOWG, 2005a, b), which are listed along a northwest-southeast direction (perpendicularly to the geological structures).

- Upper freshwater molasse from middle and early upper Miocene (consisting of floodplain sediments including puddings, sandstones and silty shales).

- Other types of molasse (narrower areas of upper marine molasse, lower freshwater molasse and lower marine molasse, the lower part of this series being in subAlpine position).

- Sub-Alpine flysch.

- Upper Penninic flysch (Schlieren flysch).

- Ultrahelvetic and Helvetic nappes (including Tertiary shallow marine formations and Cretaceous limestones from the Wildhorn nappe and Jurassic limestones from the Axen nappe).

The bedrock is mostly covered by soil (regolith) and loose materials. Most of these shallow and superficial formations have not been mapped, except for the cases where the formation reaches a sufficient extension or thickness to be considered relevant at the map scale. This is for example the case of morainic material deposited by the glaciations during the Quaternary, which is visible at several places, especially on the plateau (Trümpy, 1980). The properties (e.g. mechanical, hydrological) of the local soils strongly depend on the underlying bedrock.

\subsection{Description of the precipitation event}

The rainfall event of August 2005 in central and eastern Switzerland resulted in severe damage due to flooding and induced slope instabilities (Rotach et al., 2006). The presence of the Alps played a key role in controlling the spatial distribution of rainfall due to orographic precipitation enhancement processes. Persistent precipitation patterns were mostly found on the exposed upwind slopes under northerly and northeasterly flow conditions as studied by Foresti and Pozdnoukhov (2012) and Foresti et al. (2012). In particular, 


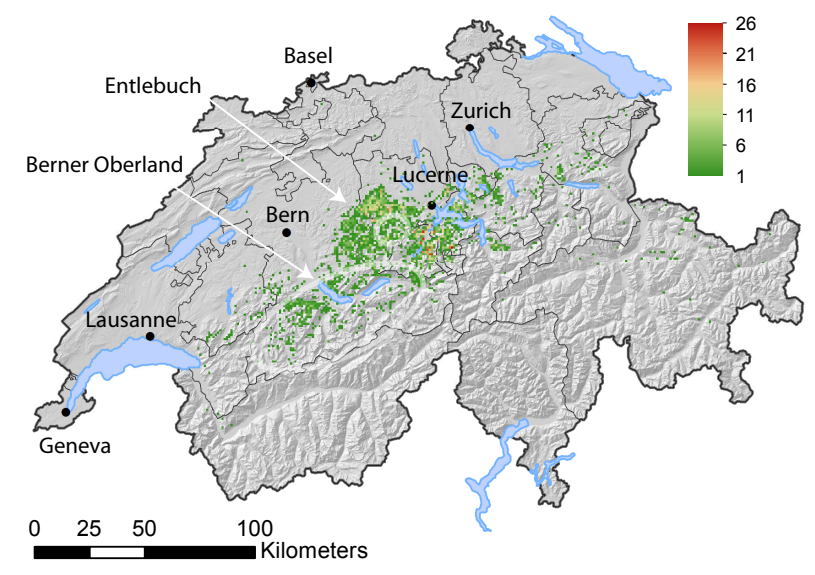

Fig. 1. Number of landslides in $1 \mathrm{~km}^{2}$ cells (after Raetzo and Rickli, 2007). White circles represent the Berner Oberland and Entlebuch regions (hillshade: ${ }^{(C)}$ Swisstopo).

the stratiform precipitation was locally enhanced by smallerscale orographic features leading to persistent initiation and enhancement of the embedded convection.

The most intense period of the event was observed between 21 and 22 August. Driven by cyclonic conditions during the first day, the moist air from the Mediterranean Sea circumvented the Austrian Alps and started approaching slightly crosswise the northern slopes of the Swiss Alps from the east. The atmospheric flow gradually turned from easterly to northerly conditions during the second day. The reduced supply of air moisture was compensated by a stronger upslope rainfall enhancement which extended the duration of precipitation. The return period for $48 \mathrm{~h}$ rainfall accumulations largely exceeded $100 \mathrm{yr}$ at several weather stations mostly located in the Berner Oberland (Rotach et al., 2006). It is worth mentioning that the uncertainty of this estimation is quite important as an event of such intensity was never observed in the past at the considered weather stations.

\subsection{Landslide inventory}

As a consequence of this extreme rainfall event, many shallow landslides were triggered, mainly in the Entlebuch part of Lucerne canton and in the Bern canton. Some deep-seated landslides were observed as well and are mainly located farther southeast. A landslide inventory has been collected by Raetzo and Rickli (2007) from cantonal authorities' information and contains 5756 landslides. Although some additional attributes such as the exact timing have been registered for some of the landslides, we only dispose of the version provided in the above publication and, as a result, we only know the approximate location. However, the Federal Office of the Environment (FOEN) also provides to the cantonal authorities a tool to register the events (FOEN, 2012). An extract of this database has been provided by the

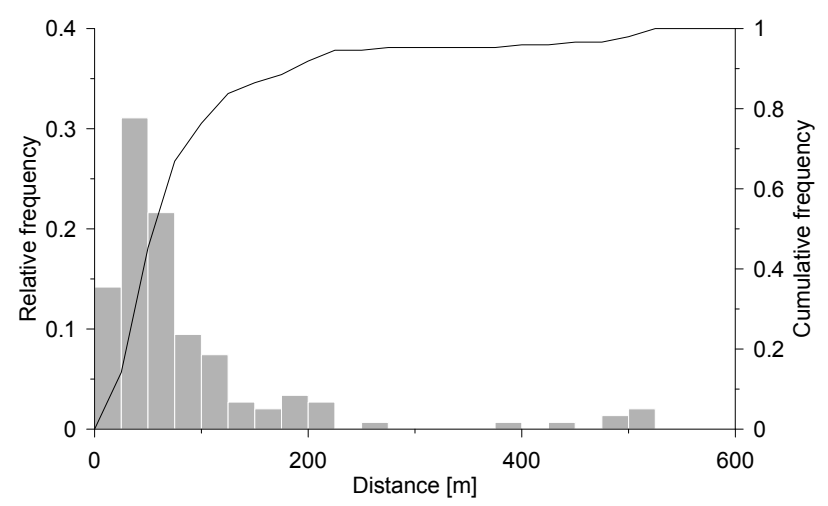

Fig. 2. Relative and cumulative frequency of the distance travelled by 148 landslides (Raetzo and Rickli, 2007).

FOEN, but contains less landslides than the one built by Raetzo and Rickli (2007), since some of the cantons report every landslide, whereas others only report one point for each set of close landslides. The uncertainty about the location of landslides complicates the analysis of their geological context.

Statistics on the landslides can be found in Raetzo and Rickli (2007) and in Rickli et al. (2008) and investigations on specific sites in Mueller and Loew (2009) and von Ruette et al. (2011). The travel distance of shallow landslides has been analysed for 148 cases and ranges from a few metres up to $500 \mathrm{~m}$ (Raetzo and Rickli, 2007). Around $75 \%$ of the landslides travelled less than $100 \mathrm{~m}$ and $90 \%$ less than $200 \mathrm{~m}$ (Fig. 2).

\subsection{Damage}

According to the Swiss Federal Institute for Forest, Snow and Landscape Research WSL, the 2005 event has been the most costly since the beginning of the collection of damage data in 1972, with a total damage cost estimated at CHF 1.83 billion (around USD 2 billion). On the other hand, in spite of being the most important event recorded, other years have been equally or more damaging regarding landslides in the past $40 \mathrm{yr}$ (Hilker et al., 2009; WSL, 2012).

Hilker et al. (2009) divided the damage values into three categories according to the cause, namely floods, debris flows and landslides (including mudflows). Landslides represent around $4.5 \%$ of the total cost and affected private properties (22\%, CHF 16.3 million) and public infrastructures (88\%, CHF 75.6 million) (Hilker et al., 2007). Private damage includes damage to buildings as well as furniture, vehicles, other property damage and loss of profits. Comparatively, public damage includes damage to waterways, roads (except small ones), railways, farming and forests. In addition to economic consequences, six casualties are to be deplored. 


\section{Risk modelling methodology}

\subsection{Introduction}

Risk is defined by Einstein (1988) as

Risk $=$ hazard $\times$ potential worth of loss,

where the hazard is the "probability that a particular danger occurs in a given period of time" and the potential worth of loss characterizes the estimated potential loss caused by an event of given intensity, which depends on the economic value and vulnerability of the object. We prefer to define hazard in terms of frequency, rather than in terms of probability since we are dealing with events that can be considered as repetitive over a large area (van Westen et al., 2006). Indeed, if the events are repetitive, Kaplan (1997) suggests to use the frequency rather than the probability (or the frequency expressed as a probability distribution), which is also more rigorous since risk is expressed in terms of cost per year.

The methodology described hereafter is a partial risk calculation. Indeed, a single precipitation event is used as an input, which does not allow accounting for the temporal component of the hazard. However, the hazard is considered by its spatial aspect. In a first phase, the spatial distribution of the total rainfall accumulation is estimated using data from a dense network of rain gauges and 3 additional operational Cband weather radars (Sect. 3.2). The second phase studies the statistical distribution of landslides as a function of precipitation accumulation and lithological type (Sect. 3.3) and is used to estimate the probability of landsliding in $1 \mathrm{~km} \times 1 \mathrm{~km}$ cells given the occurrence of the precipitation event. These first steps do not however completely consider the spatial aspects of the hazard. Indeed, the exact location as well as the propagation probability are virtually assessed using principles of stochastic geometry, and represent the probability of buildings to be affected by circular landslides within a given cell. The potential worth of loss is then assessed by using the estimation of the mean cost of the event and by artificially adding a variability accounting for the diversity of the element at risk values and vulnerabilities, as well as the landslide intensities (see Sect. 3.4).

\subsection{Spatial analysis of rainfall}

MeteoSwiss operates an automatic network of 76 weather stations and a dense network of additional 363 rain gauges. The automatic network measures rainfall with a temporal resolution of $10 \mathrm{~min}$ while the second only reports daily accumulations from 05:40 to 05:40 UTC of the next calendar day. An additional network of $3 \mathrm{C}$-band radars is used to measure precipitation with higher spatial resolution. The operational radar data processing chain for quantitative precipitation estimation (QPE) at MeteoSwiss includes the removal of ground clutter, correction for the vertical profile of reflectivity in connection with the bright band effect, climatological rain gauge adjustment, the interpolation from polar coordinates to a Cartesian grid, and the use of a fixed climatological $Z-R$ relationship (refer to Germann et al., 2006, for more details). A geostatistical method for real-time adjustment with rain gauges was only recently implemented by Sideris et al. (2013). For long-term evaluation of the radar QPE accuracy against rain gauges refer to Gabella et al. (2005). The radar QPE product used in this paper is a $1 \mathrm{~km} \times 1 \mathrm{~km}$ grid of the rainfall accumulation during the period 18-23 August 2005.

Despite these corrections, the product still contains residual ground clutter and biases due to the blockage of low level radar beams, particularly in the inner Alpine valleys. To partially account for these issues, an artificial neural network was applied to blend the radar-based QPE map with the rain gauge rainfall accumulations. A 3-H-1 multiLayer perceptron (MLP) was trained to predict the rainfall amount observed at the rain gauges as a function of 3 variables: the geographical location represented by the Swiss easting and northing coordinates and the radar QPE product which acts as an external drift. The geographical coordinates account for the observed biases between rain gauges and radar-based QPE, which show a significant spatial dependence. A conjugate gradient algorithm was employed to train the network. A low number of hidden neurons $H=6$ was chosen to obtain a smooth representation of the spatial rainfall biases. The optimal model was selected by minimizing the leave-one-out cross-validation root-mean-square error (RMSE). A randomly sampled test set of 137 stations was kept to evaluate the expected prediction RMSE, which is of $25.3 \mathrm{~mm}$. No quantitative assessment of the performance of the MLP model against geostatistical approaches (e.g. Sideris et al., 2013) was carried out. Some preliminary comparisons with kriging with external drift and additional details on the MLP model are reported in Foresti et al. (2010). The regularized MLP solution is a smooth compromise between the radar and rain gauge measurements. This allows being robust to local radar overestimations due to ground clutter and the different sampling volume of radar and rain gauge measurements. The Machine Learning Office software was used for the computations (Kanevski et al., 2009).

Figure 3 illustrates the spatial analysis of the rainfall accumulation from 18 to 23 August 2005. The highest accumulations are observed on the northern slope of the Alps, in particular along a line from the Berner Oberland to the mountain range of Saentis. The spatial distribution of landslides is strongly correlated to the spatial distribution of rainfall amounts. The remaining unexplained spatial variability is due especially to the local geological and morphological settings, which control the sensitivity of the soil to the input rainfall.

\subsection{Landslide distribution}

In order to improve the georeferencing of the landslide localization extracted from Raetzo and Rickli (2007), the StorMe 


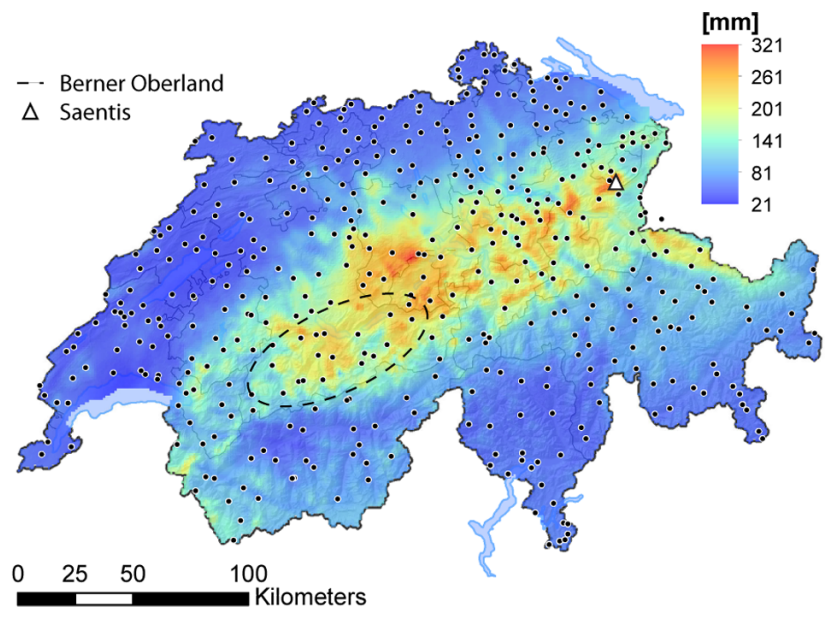

Fig. 3. Total rainfall accumulation from 18 to 23 August 2005 [mm] estimated by MLP. Dots represent the stations used for the interpolation. The dashed area (Berner Oberland) and the triangle (Saentis) correspond to the end points of a line segment representing the regions with the highest rainfall accumulation.

database (FOEN, 2012) has been used as a reference. The points known to correspond to multiple landslide events in the latter database have been removed. The remaining points are then supposed to correspond to a subset of the first landslide map. As a result, each point of the StorMe database should have its equivalent in the landslide map. The distance from each point of the StorMe database to its nearest neighbour in the landslide inventory has then been reduced by optimizing 2 scale and 2 position factors affecting the coordinates of the points in the landslide inventory. For the optimization, the median distance was preferred to another parameter, such as the RMSE, in order to ignore potentially remaining points corresponding to multiple landslides. The median distance obtained after optimization is $104 \mathrm{~m}$. To be consistent with the precipitation map, the landslide points have been transformed into a raster grid with a resolution of $1 \mathrm{~km} \times 1 \mathrm{~km}$, by counting the number of landslides in each cell (Fig. 1).

To establish a predictive relation linking the precipitation amounts and the lithological type to the landslide probability, a categorical lithological information should be coded into a set of variables describing the presence of a given lithological type into a cell. For this purpose, the geotechnical map of Switzerland has been used (SGTK, 2012). This map combines the shape of the $1: 500000$ geological map (University of Bern and FOWG, 2005b) with the attributes of the four 1: 200000 geotechnical maps (De Quervain and Frey, 1963, 1965, 1967; De Quervain and Hofmänner, 1964). The purpose of the latter maps is to transmit the geological information relevant for non-geologists involved in different activities dealing with the ground, especially for civil engineering. The map has been simplified into 4 units, loosely

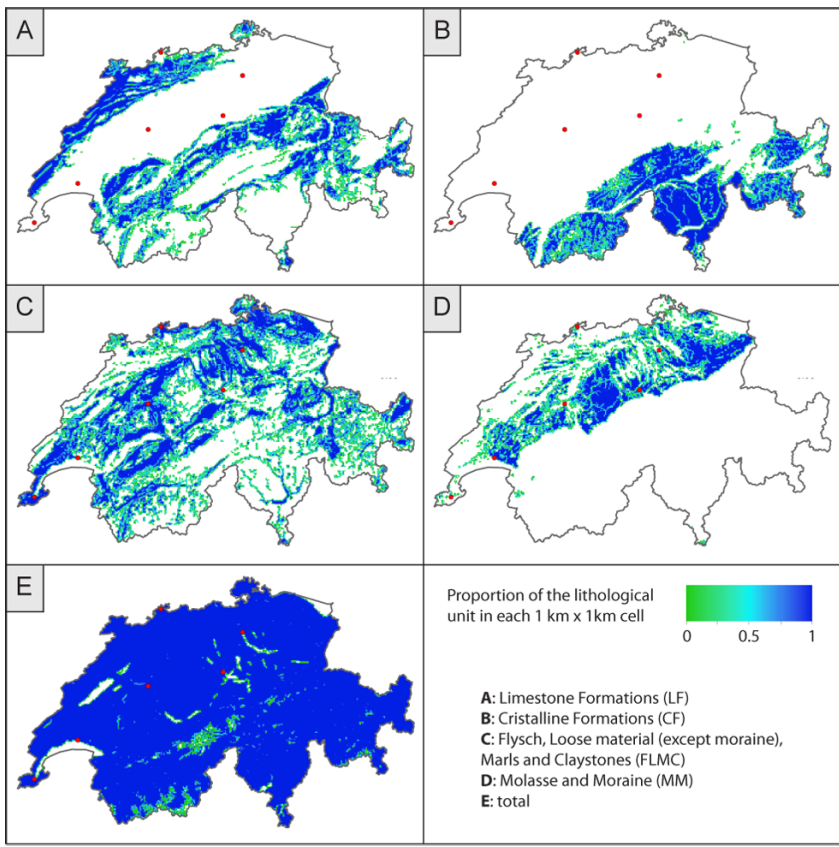

Fig. 4. Probabilistic lithological maps showing the proportion of each lithological unit. Values range from green (lithological group slightly present) to blue, whereas white means that the lithological group is non-existent in the cell; (A) limestone formations (LF); (B) crystalline formations (CF), (C) flysch, loose material (except moraine), marls and claystones (FLMC), (D) molasse and moraine $(\mathrm{MM})$ and (E) total. In map (E), white tones mark the absence of lithological formations (i.e. lakes, glaciers) and other countries, while green tones depict their partial presence within the model cell, which occurs when the cumulative proportion of the 4 units is below 1.

based on the 6 units used by Rickli et al. (2008) to assess the landslide density distribution of the event:

- limestone formations (LF),

- crystalline formations (CF),

- flysch, loose material (except moraine), marls and claystones (FLMC),

- molasse and moraine (MM).

The vector map is transformed into 4 raster maps displaying the proportion covered by the lithological groups in each cell (Fig. 4a-d). These products do not allow to relate directly each landslide to only one lithological unit. Therefore, in order to take into account the uncertainty on the lithology involved in each landslide, a stochastic strategy is employed. A lithology is randomly assigned to each cell according to the initial lithological proportions. This is achieved by sampling a random variable $0<=u<=1$ and comparing it to the cumulative probability distribution of lithology classes (Fig. 5). This operation is performed several times to average the results. 


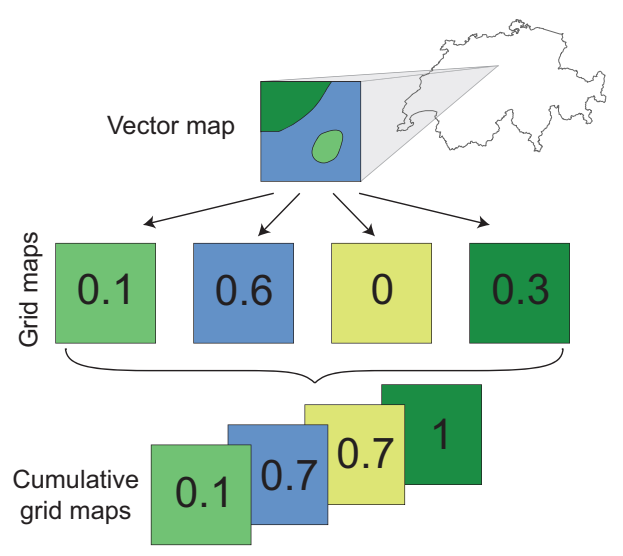

Fig. 5. Schematic transformation of the vector geotechnical map into 4 grids containing the proportion of each lithology individually and, then, into 4 grids which give, for each cell, the lithological units' cumulative distribution. A lithology is assigned at each model iteration by choosing a random number $0 \leq u \leq 1$. In this example, if $u=0.5$, the second geology would be assigned, since $0.1<u<$ 0.7 .

Cells that contain water (lakes or glaciers) or that are located on the Swiss border have a cumulative value below 1, since the lithology polygons only cover a fraction of the surface (Fig. 4e). As a result, if the random value $u$ is above their total cumulated value, they are not taken into account in the iteration. To build the probabilistic relation, the total number of landslides considered might then be lower than the actual number of landslides. To account for this effect, the landslide map is divided by the cumulated value of the lithological grids. This operation actually expresses the landslide map in terms of the number of landslides per $\mathrm{km}^{2}$, since the cumulated value of the lithological grids is the surface of land (in $\mathrm{km}^{2}$ ).

The precipitation field has been divided into 6 classes to have a sufficient number of landslides in each class while being enough discriminative in terms of precipitation levels. As visible in Fig. 6, the histogram is highly skewed and only $10 \%$ of Switzerland exceeds $200 \mathrm{~mm}$ of rain.

Figure 7 summarizes the data processing workflow. The output of the model is a cumulative distribution of the expected number of landslide given the geology and the precipitation amount. To allow a generalization of these results, gamma distributions were fitted to the data by minimizing the RMSE between the observed and modelled distributions in order to model the number of landslides as a function of precipitation amount. The 2 parameter form of the gamma cumulative distribution function is given by (Johnson and Kotz, 1970)

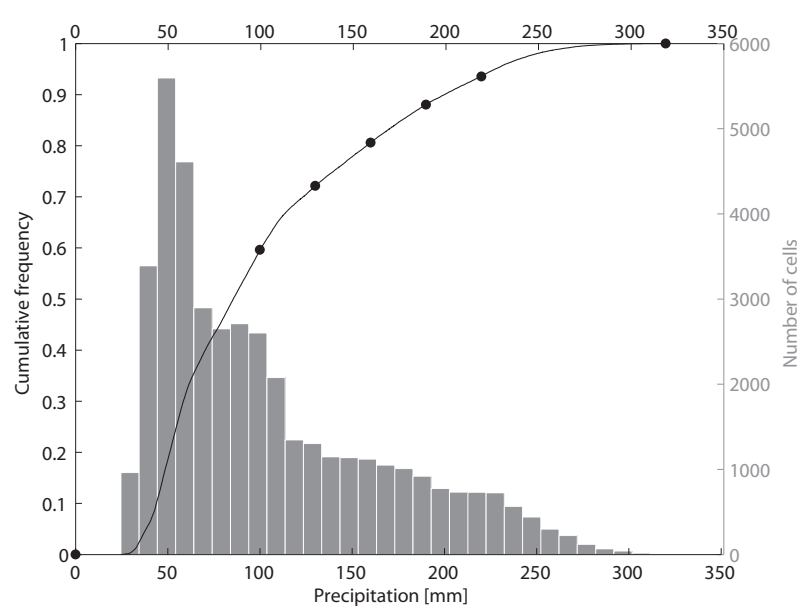

Fig. 6. Cumulative distribution of the spatial precipitation amounts. Dots show the limits of the 6 classes and are rounded to the upper value.

$F(x)=\frac{1}{\beta^{\alpha} \Gamma(\alpha)} \int_{0}^{x} t^{(\alpha-1)} e^{-\frac{t}{\beta}} \mathrm{d} t$,

where $\alpha$ is the shape parameter, $\beta$ is the scale parameter and $\Gamma(x)$ is the generalized form of the factorial function, such as $\Gamma(x)=(x-1)$ ! if $x$ is a positive integer. The gamma function is defined as

$\Gamma(x)=\int_{0}^{\infty} e^{-t} t^{x-1} \mathrm{~d} t$.

Since the gamma distribution is a continuous distribution whose domain is $0 \rightarrow \infty$, it is not exactly suitable to fit discrete data, especially as the most frequent number of landslides is expected to be $x=0$ and as $F(x=0)$ is null, whatever the values of $\alpha$ and $\beta$. As a workaround for these issues, the distribution has been virtually modified to extend the definition domain from $-1 \rightarrow \infty$ as:

$F(x)=\frac{1}{\beta^{\alpha} \Gamma(\alpha)} \int_{0}^{x+1} t^{(\alpha-1)} e^{-\frac{t}{\beta}} \mathrm{d} t$.

This modification is virtual since the distributions' fitting is made by shifting the $x$ values, i.e. by using the value $F(x=0)$ for $x=1$, which is easier than modifying the function. The consequences of this modification are discussed below.

To estimate the predictive ability of the model, a second part consists in using the distribution of the number of landslides according to the precipitation class and lithology previously assessed to simulate different potential consequences 


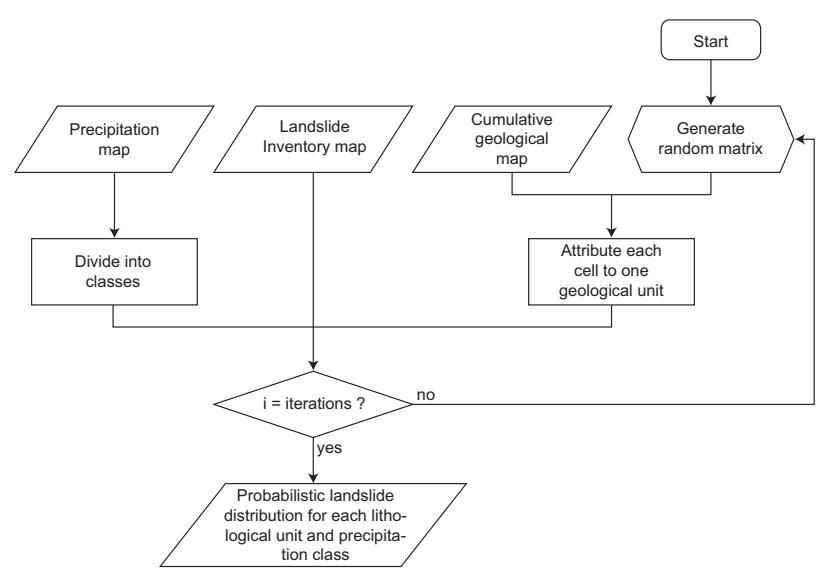

Fig. 7. Flow diagram showing the assessment methodology used to obtain the cumulative frequency of the number of landslides per lithological unit and precipitation class.

of the precipitation event using a Monte Carlo approach. This step illustrates the uncertainty of the model on the consequences of a given precipitation event. Indeed, since we consider that the landslides are controlled only by the precipitation and the lithology, this step gives the variability resulting from this simplification. The workflow of this step is given in Fig. 8. Both the raw distributions and the gamma distributions are used.

Since gamma parameters have been fitted with shifted values, the unmodified inverse distribution will overestimate the number of landslides. However, as the gamma distribution is continuous and as we need to obtain the number of landslides in integers, the results of the inverse function for a given quantile can be rounded down to be consistent with the original data. Matlab ${ }^{\circledR}$ was used to iteratively derive the gamma cumulative distribution as there is not analytical solution (Johnson and Kotz, 1970).

\subsection{Impact assessment}

The impact assessment consists of two main steps, which are evaluating how many buildings will be reached and estimating an associated cost.

In order to assess the number of affected buildings, geometrical probabilities are used. The concept used in this model is inspired from Buffon's clean tile problem, which consists of calculating the probability for a coin to fall on the crack separating two tiles of a paved ground (Mathai, 1999; Weisstein, 2013). For square tiles, the probability that a circular coin of diameter $d$ falls completely inside a square of side $l$ (with $l>d$ ), is given by the ratio of a square of side $l-d$ with the tile of side $l$. The smaller square corresponds to the tile eroded by a buffer of size $d / 2$ (Fig. 9, left). Therefore, the probability for the coin to fall on the crack is the ratio of the area between the plain and the dashed lines $\left(l^{2}-(l-d)^{2}\right)$

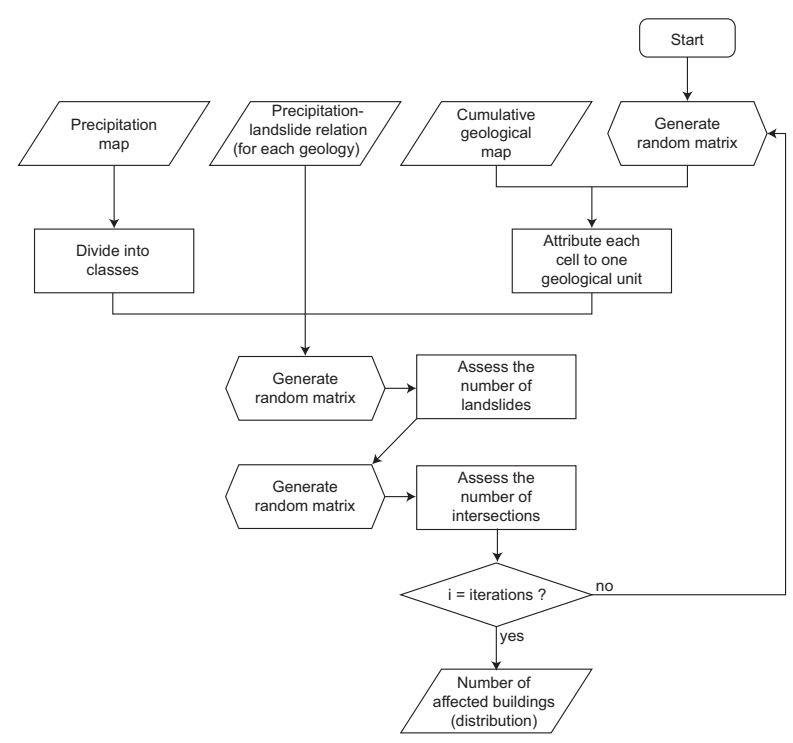

Fig. 8. Flow diagram showing the assessment methodology used to obtain the number of affected buildings.

and the area of the bigger square. Buffon also investigated the "needle problem", which consists of calculating the probability that a needle falling on a ground made of infinite parallel strips of equal width falls on one of the lines (Mathai, 1999). In contrast, the falling object is, in the needle problem, not only characterized by the position of its centre, but also by its orientation. As a result, dilating the lines by a buffer is not suitable to solve the problem and Buffon's solution cannot be straightforwardly extended to other objects than the straight lines.

To assess the conditional probability for a landslide to reach a building, the coin of Buffon's problem is replaced with circular landslides of diameter $d$, and the cracks between the tiles are replaced with the actual buildings (Fig. 9, right). Therefore, adding a buffer of a distance $d / 2$ to the buildings allows one to compare the area covered by the expanded buildings with the total area, which corresponds to the conditional probability for a landslide to reach a building. At this step, it is considered that the landslide has the same probability to occur anywhere inside the considered area.

Assuming circular landslides is a simplification which might have consequences on the model, since, as illustrated by the needle problem, an elongated shape is more likely to affect the buildings. Moreover, the shape of the landslides is expected to be elongated. As a consequence, the circle diameter is set to $200 \mathrm{~m}$ in order to completely include $90 \%$ of the landslides, since the distance measure corresponds to the largest dimension (Fig. 2), i.e. the length of the landslide. This diameter results in an overestimation of the landslide surface, but it takes indirectly into account the landslide geometry and provides a slightly pessimistic risk estimation in terms of the number of affected buildings. Thus, a $100 \mathrm{~m}$ 

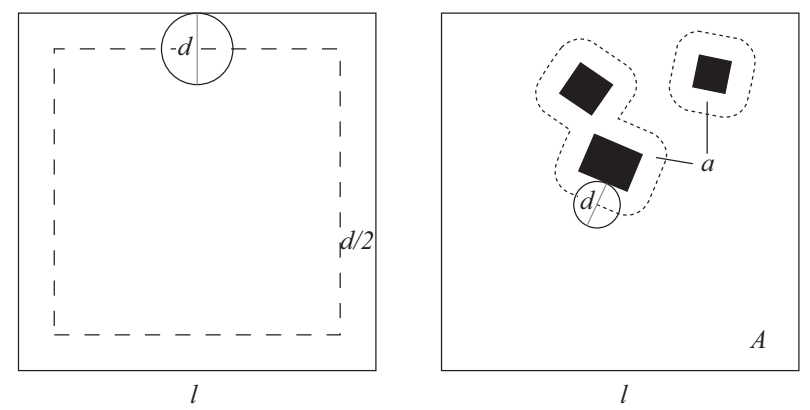

Fig. 9. Left: Buffon's clean tile problem (modified from Mathai, 1999). The probability for the coin to touch the limit of the tile is given by the ratio between the dashed square $\left(\operatorname{area}=(l-d)^{2}\right)$ and the plain square $\left(\right.$ area $=l^{2}$ ). Right: The probability for a circular landslide of diameter $d$ to reach a house is given by the ratio of the buildings expanded with a $d / 2$ buffer $(a)$ with the total area $(A)$.

buffer has been added to the 1814667 buildings extracted from the vectorized landscape model of Switzerland (Vector25, ${ }^{\odot}$ swisstopo). Then, the total surface has been compared with each cell surface to obtain the impact probability. It has to be mentioned that impact is only considered with a Boolean approach, which means that a landslide can affect a building or not, but the potential for one landslide to affect several buildings is not considered. It should also be noted that the buffers are made before cutting shapes into cells in order to take into account the possibility for a landslide occurring in a given cell to reach a house located close to the border of an adjacent cell.

However, a shallow landslide preliminary hazard map exists at Switzerland scale (Geotest et al., 2006) and provides a global area where shallow landslides can occur, including both the initiation and propagation zones. This map is based on a global analysis in two steps: first the stability is assessed using an infinite slope analysis (model SLIDISP, Liener et al., 1996), then propagation prone areas are assessed with a model adapted from debris flow (model SLIDESIM, based on Gamma, 2000). The final version of this map combines both areas without further attributes. Thanks to this map a small modification is made to the impact probability. If a landslide occurs in a cell where the hazard map exists, it is considered that the landslide will occur inside the area covered by the hazard map. Therefore, the ratio $a / A$ described in Fig. 9 becomes $(a \in S) / S$, where $S$ is the surface covered by the hazard map. The impact probability map including this modification is given in Fig. 10. The hazard map has however not been used yet to assess the location of the landslides, but a usage of this map for the landslide distribution has to be considered. Indeed, only 8 landslides $(0.14 \%)$ were located in cells with no hazard according to the map and 133 $(2.31 \%)$ were located within cells where less than $10 \%$ of the surface is covered by the hazard map. This tends to indicate that this preliminary hazard map is realistic, but since

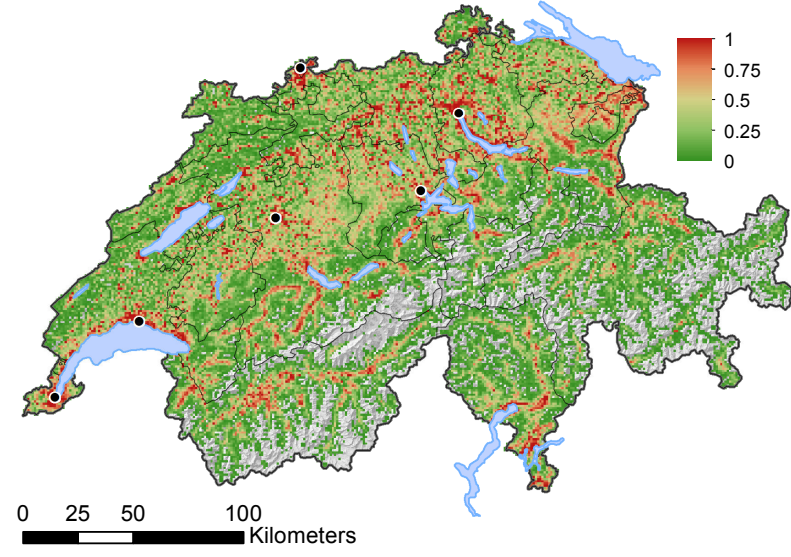

Fig. 10. Impact probability map displaying the conditional probability for a $100 \mathrm{~m}$ radius circular landslide to affect a house for each cell of the model. Dots correspond to the cities visible in Fig. 1 (hillshade: ${ }^{\circledR}$ Swisstopo).

there is an uncertainty on the landslide locations, an in depth analysis of the landslide locations with regard to the hazard map cannot be made.

The estimation of the associated cost is more complicated as the value of the buildings is not known. This information could be obtained from the buildings' insurances for 19 of 26 cantons, for which a public insurance exists and is mandatory. However, a suitable vulnerability curve linking the landslide intensity, characterized by parameters such as depth or area, to the damage rate, is difficult to assess. The lack of knowledge on the precise landslide characteristics and location as well as the inherent variability of the elements at risk complicates even more the assessment of the vulnerability (Galli and Guzzetti, 2007). Therefore, in order to keep the precision of the model consistent with the previous step, we chose not to use a value and a vulnerability curve to assess the damage cost, but to assess it directly from the 2005 event mean damage cost. This cost is estimated by dividing the total damage cost induced by landslides to private infrastructures (CHF 16.3 million) by the expected number of affected buildings. The latter is obtained by summing over all grid cells the product between the number of landslides (Fig. 1) and the impact probability (Fig. 10). This approach results in 2260 affected buildings, implying a mean cost $\bar{x}$ of CHF 7211 per building. No uncertainty is considered for this parameter.

It is apparent that damage costs are varying. Therefore, to reproduce a possible distribution of costs, a statistical distribution is chosen. Thus, the expected damage cost $x$ for a given building is assumed to follow an exponential distribution with probability density function (e.g. Ross, 2010) as

$f(x)=\left\{\begin{array}{ll}\lambda \exp (-\lambda x), & x \geq 0 \\ 0, & x<0\end{array}\right.$. 

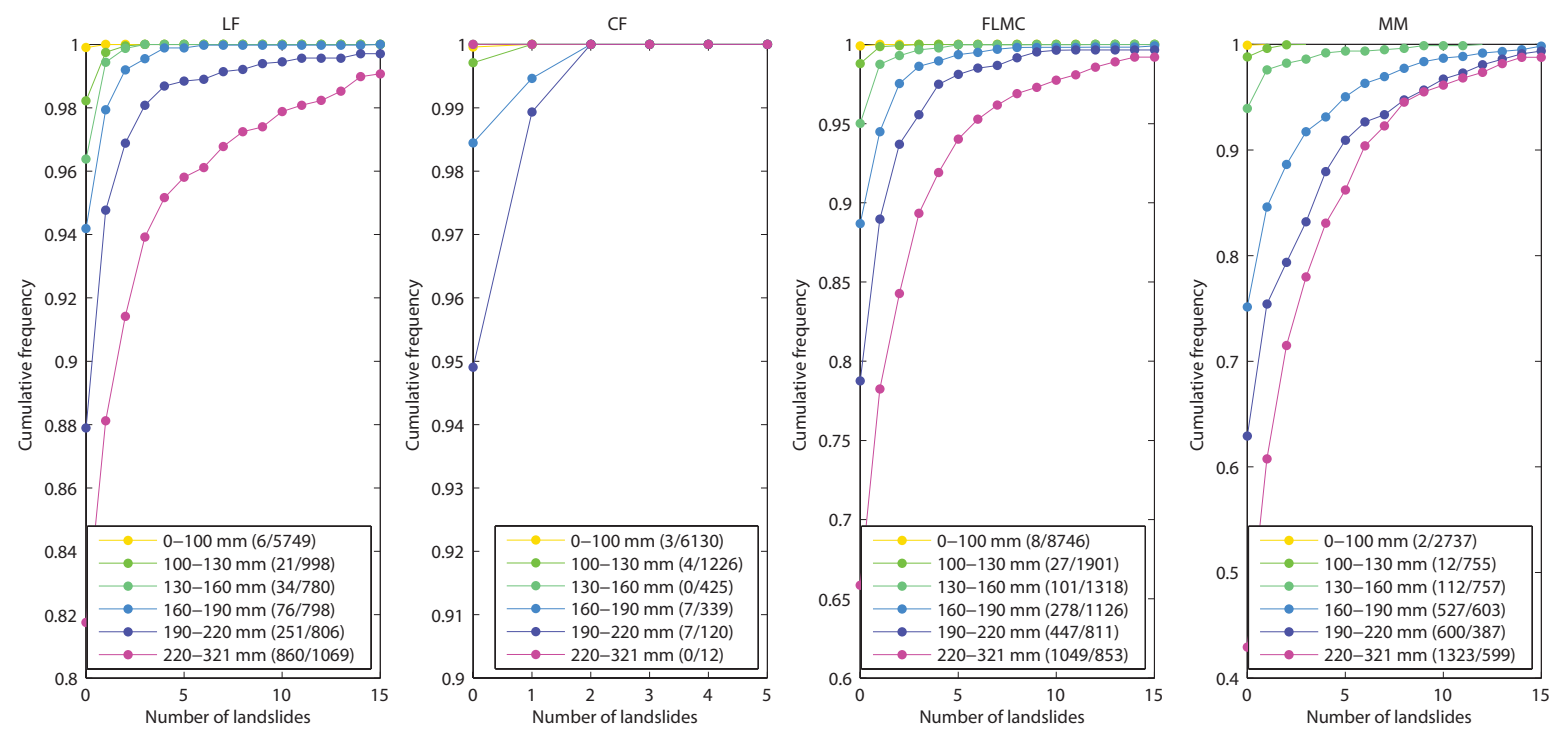

Fig. 11. Landslide relation with precipitation and lithological group. The curves for small precipitation amounts are not always visible because of the low number of landslides. Note that scales are different. Numbers between brackets are respectively the number of landslides in the cells and the number of cells in the class, averaged over the iterations.

The distribution is only defined in terms of its first moment $1 / \lambda$, which is equal to $\bar{x}$, namely the expected mean damage cost per building assumed for the 2005 event.

The generation of exponential variates is obtained by sampling from the quantile distribution, which is given by the inverse function of the exponential cumulative distribution as

$F^{-1}(u)=x=-\frac{\ln (1-u)}{\lambda}$,

where $u$ is a uniformly distributed random number between 0 and 1 . The exponentially distributed damage cost is sampled for each case of impact identified by the model.

The fat-tailed nature of the exponential distribution allows obtaining a more realistic estimate of the damage costs than a normal or triangular distribution and does not need the estimation of the second moment characterizing the variance of the distribution. The latter is a useful feature as the statistical distribution of the damage costs per building is not known in our particular case. The log-normal distribution also has heavy tails and was successfully used to model the cost associated to floods (Merz et al., 2004). However, due to the larger number of degrees of freedom, it is also not suitable for our application.

\section{Results}

The statistical distribution of landslides as a function of precipitation amount and lithological group is given in Fig. 11 and results from 10000 iterations of the model. The probability to observe a given number of landslides in a given lithological group is a monotonically increasing function of the precipitation amount. CF show a very little susceptibility to landslides compared to the other groups as evidenced by the low number of observed landslides. With similar precipitation amount, MM formations tend to have a higher probability to contain at least one landslide than FLMC or LF. However this relation is less evident for a larger number of landslides.

Table 1 shows the fitted values of the gamma distribution (missing data denotes that the fitting did not converge in the allowed number of iterations), whereas Fig. 12 displays these values graphically. CF have to be considered with caution because of the low number of samples. The $\alpha$ parameter (shape), characterizes the central location of the distribution, while the $\beta$ parameter (scale) characterizes its dispersion. A general increase in both $\alpha$ and $\beta$ parameters with precipitation amount can be observed, although some values are not following the general linear trend. This is especially the case for $\alpha$ for LF and for $\beta$ for the highest precipitation class.

The general increase of both parameters is a desirable property and is in accordance with our prior expectations. In fact, increasing precipitation amounts increase the expected number of landslides (represented by $\alpha$ ) and the dispersion of the distribution (represented by $\beta$ ). Higher $\beta$ values are representative of heavy tails, which means that the probability of observing a high number of landslides rises with increasing precipitation amount.

The spatial distribution of the number of landslides was computed following the procedure described in Fig. 8 using both the raw data and the gamma fits and performing 10000 iterations for each. However, since gamma distributions have 
Table 1. Fitted parameters of the gamma distribution.

\begin{tabular}{|c|c|c|c|c|c|c|c|c|c|c|c|c|}
\hline \multirow{2}{*}{$\begin{array}{r}\text { Precipitation } \\
{[\mathrm{mm}]}\end{array}$} & \multicolumn{3}{|c|}{ LF } & \multicolumn{3}{|c|}{$\mathrm{CF}$} & \multicolumn{3}{|c|}{ FLMC } & \multicolumn{3}{|c|}{ MM } \\
\hline & $\alpha$ & $\beta$ & RMSE & $\alpha$ & $\beta$ & RMSE & $\alpha$ & $\beta$ & RMSE & $\alpha$ & $\beta$ & RMSE \\
\hline $0-100$ & - & - & - & - & - & - & - & - & - & - & - & - \\
\hline $100-130$ & 0.149 & 0.666 & $1.77 \times 10^{-5}$ & - & - & - & 0.112 & 0.643 & $9.56 \times 10^{-5}$ & 0.042 & 1.148 & $1.94 \times 10^{-4}$ \\
\hline $130-160$ & 0.255 & 0.685 & $6.28 \times 10^{-5}$ & 0.118 & 0.012 & 0.00 & 0.144 & 1.245 & $7.19 \times 10^{-4}$ & 0.059 & 3.632 & $1.72 \times 10^{-3}$ \\
\hline $160-190$ & 0.127 & 1.570 & $2.44 \times 10^{-4}$ & 0.052 & 1.195 & $3.54 \times 10^{-4}$ & 0.159 & 2.421 & $1.26 \times 10^{-3}$ & 0.193 & 5.798 & $2.14 \times 10^{-3}$ \\
\hline $190-220$ & 0.139 & 2.962 & $3.28 \times 10^{-3}$ & 0.279 & 0.775 & $4.60 \times 10^{-4}$ & 0.242 & 3.077 & $2.45 \times 10^{-3}$ & 0.282 & 6.835 & $6.65 \times 10^{-3}$ \\
\hline $220-321$ & 0.108 & 8.846 & $3.57 \times 10^{-3}$ & 0.118 & 0.012 & 0.00 & 0.290 & 5.133 & $3.18 \times 10^{-3}$ & 0.566 & 4.653 & $3.71 \times 10^{-3}$ \\
\hline
\end{tabular}
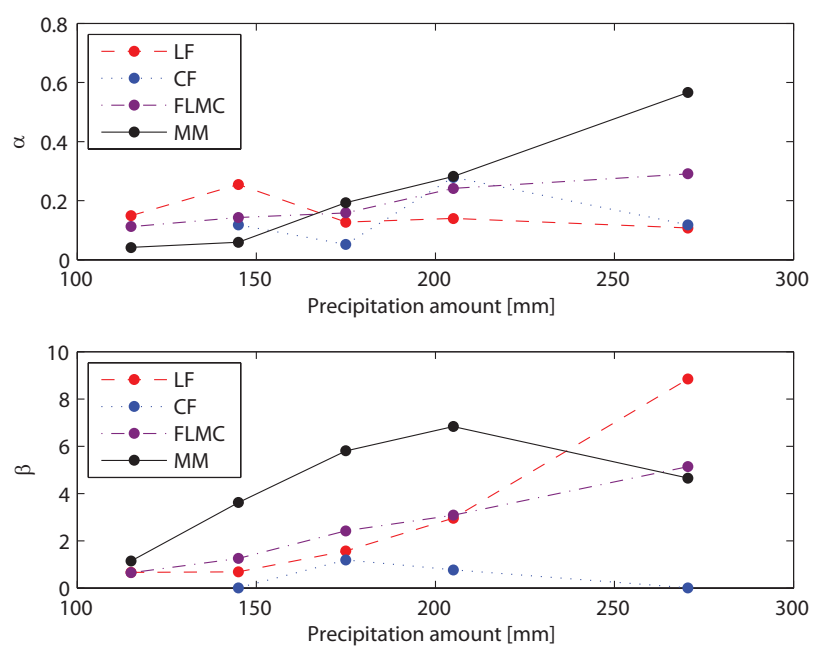

Fig. 12. Fitted parameters for $\alpha$ and $\beta$ of the gamma distribution.

not been fitted for some of the precipitation classes, raw data have been used instead of gamma distributions when not available. The mean modelled number of landslides with gamma fits is given in Fig. 13 and is very similar to the mean number of landslides modelled with raw data (not shown). The spatial pattern is relatively similar to the spatial distribution of rainfall amounts, with two remarkable differences. First, the relation between precipitation amount and number of landslides is not linear, which implies that areas with low precipitation amounts show a null to very low number of landslides. The second difference is due to the sharp geographical transitions between the lithological units, which lead to sharp transitions in the modelled number of landslides. An illustrative example occurs when moving from the $\mathrm{MM}$ formations to the $\mathrm{CF}$, which strongly reduces the number of landslides (see Fig. 4). These results seem to be in good agreement with the observed distribution of landslides (Fig. 1).

\subsection{Impact assessment}

Although the number of landslides is reproduced, the expected number of hit buildings is almost never reached in

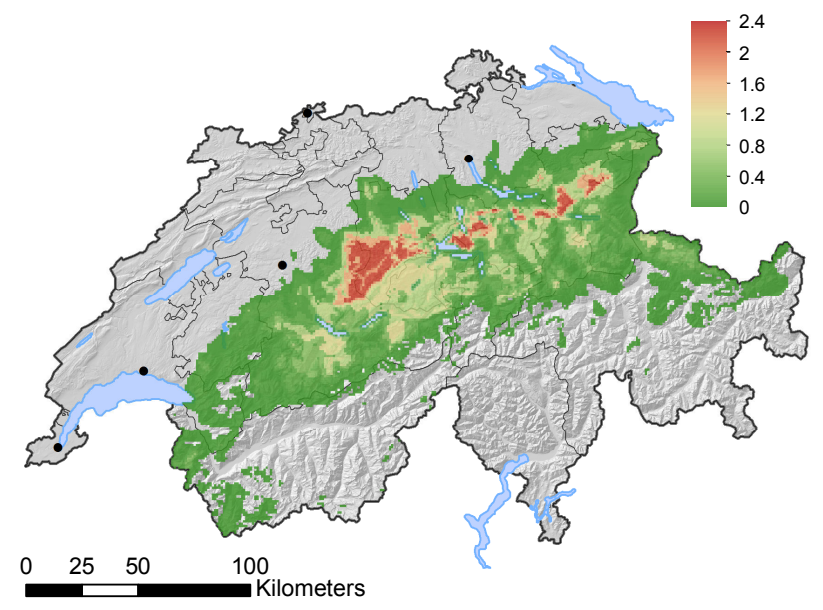

Fig. 13. Mean modelled number of landslides with the gamma functions. No colour is displayed on the cells that never contain landslides.

the simulations (Fig. 14). Indeed, the expected number of affected buildings for the event is 2260 , whereas the simulations return a mean of 1689.5 for raw data and 1665.8 for gamma fits. As a consequence, the damage amount is not reached either since it is derived from the latter. It is not yet clear why the observed total number of hit buildings is underestimated by the model. One possible reason could be that the landslide localization is highly correlated with the location of the buildings. To test this hypothesis, we compared the impact probability of cells within which landslides actually occurred to the impact probability of cells in which landslides were modelled (the impact probability is taken into account $n$ times if the number of landslides $n$ in the cell is greater than 1, for both curves). This comparison indicates that the modelled landslides tend to occur in cells with lower impact probability than the actual landslides (Fig. 15).

\section{Discussion}

The landslide model presented in this paper only considers precipitation amounts and geology as input parameters. However, other variables such as terrain slope, soil thickness 

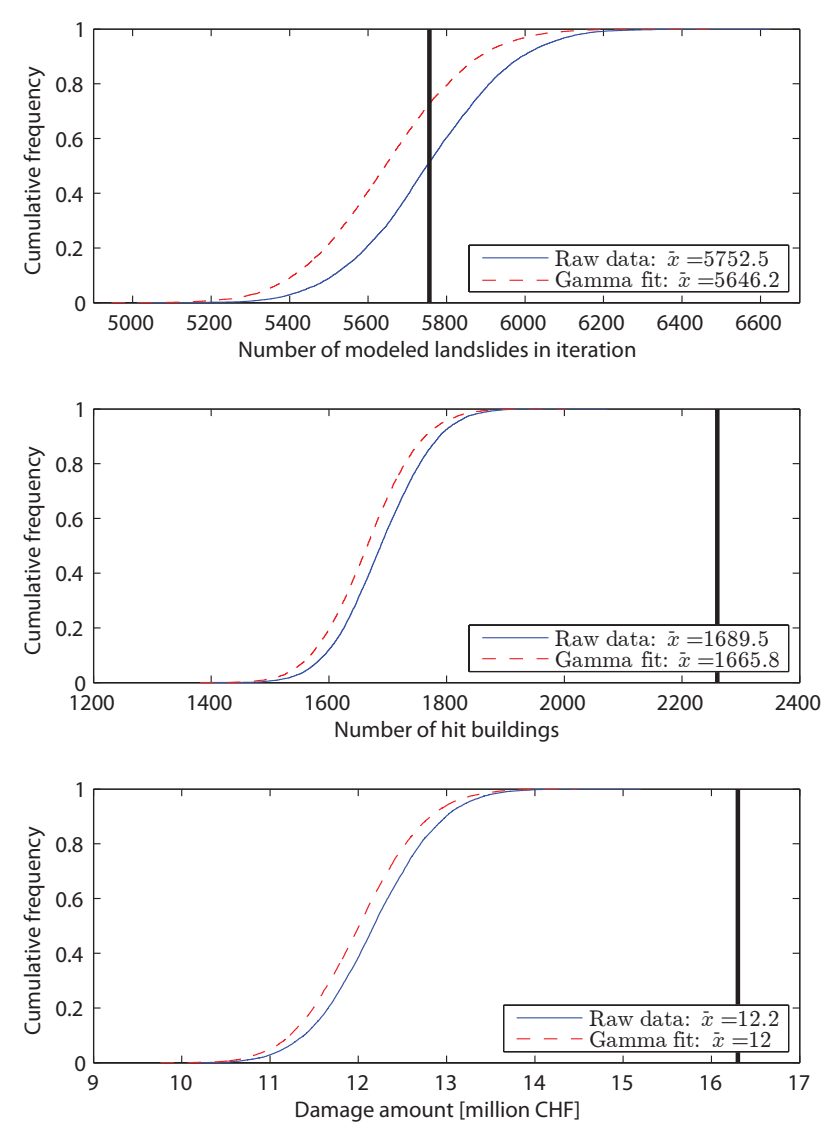

Fig. 14. Number of landslides, number of hit buildings and damage amount calculated from raw data and gamma fits. Mean value $\bar{x}$ for each line is displayed on the graph, whereas black lines correspond to the data of the event or the expected number of affected buildings. 10000 iterations have been computed.

and permeability contrast, for example, play a key role in shallow landslide generation. These variables are either hard to measure over a large domain, e.g. the soil thickness, or show spatial variability at extents which are smaller than $1 \mathrm{~km} \times 1 \mathrm{~km}$ resolution, e.g. the terrain slope. Additionally, the uncertainty of the landslide inventory does not allow matching the location of the landslide with such high resolution variables. As a consequence, the $1 \mathrm{~km} \times 1 \mathrm{~km}$ resolution model only gives information about the large-scale pre-conditioning factors for landslide generation. Smallerscale features may affect the process of landslide triggering in a significant way and should be taken into account to extend this kind of model to a higher resolution. Furthermore, this model is based only on one single event and should be compared with other similar rainfall events. In particular, it should be compared with similar events producing landslides in different geological settings, to validate the aggregation of the different lithologies into four main units. Indeed, landslide susceptibility might be different in Jura limestones than in pre-Alpine limestones, for example.

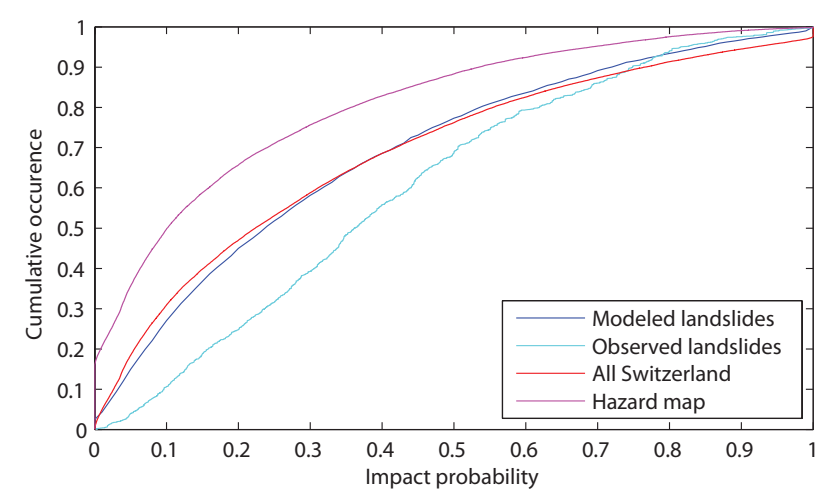

Fig. 15. Comparison of the impact probability of the cells where landslides occurred and where landslides have been modelled (if $n>1$ landslides occur in a cell, the impact probability of the cell is considered $n$ times). As a comparison, the distribution over all of Switzerland is shown, as well as the results for the existing hazard map (weighted by the surface of the cell included in the hazard map).

Lithological information is also very coarse at the working scale and local variations could affect the susceptibility. Furthermore, shallow landslides are sensitive to the properties of the soil layer, for which generally no map exists.

The annual probability to exceed a given total damage cost could be assessed by analysing different precipitation events, which are weighted based on their frequency of occurrence (return period). This step is essential in order to obtain a mean annual cost as well as an exceedance probability curve. One possibility to generate a large number of rainfall fields to appropriately represent the full risk estimation could be based on design storms (Seed et al., 1999). Stochastic rainfall fields could be generated according to a given return period and be used to simulate the spatial distribution of landslides under extreme rainfall conditions. Attempts have been made to use a return period in order to predict landslide triggering, but they were mainly performed at local scale (e.g. Iida, 1999; D'Odorico et al., 2005; Iida, 2004; Tarolli et al., 2011) and would therefore not be suitable for a larger area, since the spatial variability is not taken into account. However, the spatial distribution of rainfall by means of data with a smaller time step (in this case satellite data) has been used for early warning (e.g. Apip et al., 2010), but as far as we know, it has not been used as a starting point to simulate potential future events. Furthermore, for precipitation events with long return periods, the uncertainty on the frequency is rather high, as mentioned in Sect. 2.3 for this event. This would add uncertainty to the risk analysis.

Another issue concerns the landslide timing. We used the precipitation amount of the whole event (6 days) as a predictor for landslide occurrence. But, shallow landslides are known to be sensitive to the intensity and duration of the rainfall, as well as to the hyetograph shape (D'Odorico et al., 
2005). There are two main reasons for this simplification. The first is the lack of data on the exact timing of landslides, which does not allow the analysis of the temporal precipitation pattern preceding their triggering. The second reason is due to the uncertainty of the radar QPE product, which is higher when used to analyse rainfall time series at high temporal resolutions, for instance hourly or $10 \mathrm{~min}$ accumulations. The spatial distribution of QPE accuracy can still be affected by some residual ground clutter, which overestimates the true rainfall amount, and by the blockage of low level beams, which leads to the underestimation of ground rainfall due to using only the beams aloft. Wüest et al. (2010) present a method to obtain hourly precipitation fields by disaggregating the daily rain gauge measurements with higher resolution radar fields. If the timing of landslide occurrence was known, this dataset would be a valuable source of information. However, the product is not accompanied by uncertainty estimates. A possible solution could involve the generation of stochastic ensembles to represent the uncertainty of the radar QPE product with respect to the automatic network of 76 meteorological stations. This approach was recently implemented at MeteoSwiss (Germann et al., 2009) and could be a smart alternative to integrate ensembles of precipitation fields together with ensembles of lithological types into the landslide model.

When it comes to the damage cost assessment, due to the lack of information on the number of affected buildings and corresponding distribution of costs, a few important assumptions were made. The total number of affected buildings was estimated by means of an impact probability and this number was used to obtain a mean cost per hit building. The number of hit buildings is an uncertain estimation since it depends on the exact location of the landslides inside the cell. Indeed, we consider the probability of landsliding to be uniform within a grid cell, or within the hazard zone if it exists in the cell (which is the case in most of the cells in which landslides actually occurred). For the latter case, it takes partly into account the position of each element inside the cell, in particular the position of the slopes that might fail relatively to the buildings. However, since the hazard map is only indicative, no distinction is made between low hazard area and high hazard area. As a result, if buildings are located relatively more on low hazard area, our estimation of the number of affected buildings would be too high and, as a consequence, the mean price would be too low.

The distribution of costs was assumed to be exponential, which has a desirable long-tail property and is completely defined by its mean value. Despite being only defined in terms of the average costs, the obtained variability is supposed to adequately represent the reality. Nevertheless, with a mean cost of CHF 7211 per building, the probability to overcome CHF 500000 is almost null $\left(8 \times 10^{-31}\right.$, i.e. one case over $\left.1 \times 10^{30}\right)$. Since the mean price of a building is around CHF 1 million, this value is quite low as we know that at least one - but probably more - building has been destroyed. This could be the result of a too high number of affected buildings (since they have been estimated), which reduces the mean damage cost, or an indication of the need for using a distribution of damages with a fatter tail. However, this confirms the fact that a distribution with a fat tail is suitable. Nevertheless, since the damage cost varies independently for each affected house and since the number of affected houses is relatively high in the simulations, the effect of varying the individual damage costs is attenuated when summing over all of Switzerland. Another problem concerns the absence of data about the type of damage. Therefore, we assumed that all of the private costs are related to buildings. This simplification is not an issue as long as the cost is related to objects located close to or inside the buildings (e.g. furniture, parked cars), but is more problematic, for example, for costs related to loss of profits. However, we suppose that the vast majority is related to buildings. As a result, this model could be improved considerably if the type of damage was known. Thus, the damage assessment part has to be considered more as an example than as a reference for further vulnerability assessment.

Regarding the total number of landslides, hit buildings and the amount of damage in each simulation, the variability of the results follows more or less a normal or a log-normal distribution (Fig. 14). This distribution reflects the uncertainty induced by the lack of knowledge in the assessment of the consequences of a given precipitation event. Since the model is based on the observed landslides, to redistribute the landslides and assess the consequences, the number of modelled landslides using raw data is logically centred around the observed value. Gamma fit results tend, however, to be slightly lower than using raw data. When it comes to the number of hit buildings, the expected value is hardly ever reproduced. Since the same concept of impact probability, with the same buffer value, is used to assess the expected number of hit buildings of the 2005 event and of the simulation results, this should not be observed. By comparing the impact probability of the cells in which landslides occurred with those of the cells in which the landslides were modelled, we can observe that the cells in which landslides occurred have higher impact probability. Different hypotheses can be made in order to explain this effect. First, we might have neglected an important parameter for the localization of landslides which would be correlated to the built areas such as the repartition of the forested and non-forested areas, redistributing then the landslides in less populated areas. This seems however to be in contradiction with the fact the grid cells covered by the preliminary hazard map have a lower impact probability than the ones where landslides occurred or than the cells of the entire Swiss territory (Fig. 15). A second interpretation could be related to the quality of the inventory, which would be more complete in urbanized areas. Correcting for this effect would imply a greater total number of landslides, with more landslides on areas with low impact probability. The third one, which seems to us 
the most probable, would be that the urbanization tends to increase the susceptibility. Indeed, human activities can contribute to landslides, acting directly as a trigger or indirectly by destabilizing the slope, according to the classification of Michoud et al. (2011). Since, the trigger of the 2005 event is undeniably the rain, human activities could have played a role only as destabilizing factors. Examples of landslides triggered by rain events on slopes destabilized by the modification of pore pressure induced by pipe leaks have been observed in Switzerland, in Les Diablerets (Jaboyedoff and Bonnard, 2007) and in Lutzenberg (Valley et al., 2004). This second example is especially interesting since the landslide occurred within an event involving hundreds of landslides and debris flows, and since this particular landslide would not have occurred, thanks to the authors, without the pipe leak. Besides modifying pore pressure, pipe leaks can also destabilize slopes by weakening clay minerals (Preuth et al., 2010). In addition, the degradation of an old canalization network led to a landslide in 1930 in La Fouvrière hill in Lyon (France), killing 39 persons (Allix, 1930; Albenque, 1931). It would therefore be wise to include a parameter linked to the buildings to take account of this effect.

All things considered, the model makes simplifications in order to assess the risk for a large area rather than to be precise at local scale. Indeed, the lack of knowledge and data at the sub-grid scale is balanced by the use of stochastic simulations, which allows one to obtain a probabilistic model for landslide occurrence and associated cost.

Such kind of model might be useful to provide a rapid damage estimation following a precipitation event. Indeed, after a widespread event, the time needed by the insurance to process all claims is rather long and the exact consequences might need several months, even years to be known. Applying this model quickly after the event could provide a rough estimation of the damage costs. In a second step, modelling precipitation events assigned to a frequency could make possible the calculation of exceedance probability curves. Developments are also ongoing to assess the consequences of a landslide event for a road network with comparable models (Taylor et al., 2013).

\section{Conclusions}

This article proposes a model to assess the risk due to shallow landslides for a large region using the data from the rainfall event of 2005 in Switzerland. The first step assesses the distribution of landslides with regard to precipitation and lithology. Then the landslides are redistributed in a second step according to the relation obtained. Damage cost is obtained by means of an impact probability, which gives the probability, if a landslide occurs, that it reaches a building.

Some improvements have to be made to the model, to corroborate the relation obtained, and to improve the assessment of the impact probability, as well as the distribution of costs.
Moreover, the human influence on landslide susceptibility has to be evaluated carefully in a further step, since it appears that the landslide locations are highly correlated with the buildings. This observation tends to indicate that the human influence on slope stability is substantial. Further developments are also conceivable to complete the risk analysis by simulating stochastic rainfall events characterized by a given frequency and to analyse the consequences. This would result in a complete risk analysis able to provide the temporal distribution of damage costs.

Acknowledgements. This study was partially supported by the Canton of Vaud Natural Hazard Unit and by the the Swiss National Science Foundation project: Data mining for precipitation nowcasting (PBLAP2-127713/1). We thank the Federal Office of Meteorology and Climatology for providing the data for the rainfall event of August 2005. Stéphane Losey, from the Federal Office of the Environment, prepared and provided the Silvaprotect data, whereas Bernard Loup, from the same Office, provided the StorMe database extract. Both are also thanked for fruitful discussions. Finally, we are grateful to the two anonymous referees that helped to improve the manuscript.

Edited by: P. Reichenbach

Reviewed by: two anonymous referees

\section{References}

Albenque, A.: L'éboulement de Lyon, Ann. Geogr., 40, 105-106, 1931 (in French).

Allix, A.: L'éboulement de Fourvière (note préliminaire), Les Études rhodaniennes, 6, 454-455, 1930 (in French).

Apip, Takara, K., Yamashiki, Y., Sassa, K., Ibrahim, A., and Fukuoka, H.: A distributed hydrological-geotechnical model using satellite-derived rainfall estimates for shallow landslide prediction system at a catchment scale, Landslides, 7, 237-258, doi:10.1007/s10346-010-0214-z, 2010.

Baum, R. and Godt, J.: Early warning of rainfall-induced shallow landslides and debris flows in the USA, Landslides, 7, 259-272, doi:10.1007/s10346-009-0177-0, 2010.

Bollinger, D., Hegg, C., Keusen, H., and Lateltin, O.: Ursachenanalyse der Hanginstabilitäten 1999, Bulletin für angewandte Geologie, 5, 5-38, 2000 (in German).

Caine, N.: The rainfall intensity - duration control of shallow landslides and debris flows, Geogr. Ann. A, 62, 23-27, 1980.

Campbell, R. H.: Soil Slips, Debris Flows, and Rainstorms in the Santa Monica Mountains and Vicinity, Southern California, Professional paper 851, US Geological Survey, Washington, 1975.

Capparelli, G. and Versace, P.: FLaIR and SUSHI: two mathematical models for early warning of landslides induced by rainfall, Landslides, 8, 67-79, doi:10.1007/s10346-010-0228-6, 2011.

Cardinali, M., Reichenbach, P., Guzzetti, F., Ardizzone, F., Antonini, G., Galli, M., Cacciano, M., Castellani, M., and Salvati, P.: A geomorphological approach to the estimation of landslide hazards and risks in Umbria, Central Italy, Nat. Hazards Earth Syst. Sci., 2, 57-72, doi:10.5194/nhess-2-57-2002, 2002. 
Cardinali, M., Galli, M., Guzzetti, F., Ardizzone, F., Reichenbach, P., and Bartoccini, P.: Rainfall induced landslides in December 2004 in south-western Umbria, central Italy: types, extent, damage and risk assessment, Nat. Hazards Earth Syst. Sci., 6, 237-260, doi:10.5194/nhess-6-237-2006, 2006.

Carrara, A., Cardinali, M., Detti, R., Guzzetti, F., Pasqui, V., and Reichenbach, P.: GIS techniques and statistical models in evaluating landslide hazard, Earth Surf. Processes, 16, 427-445, doi:10.1002/esp.3290160505, 1991.

Cascini, L. and Versace, P.: Relationship between rainfall and landslide in a gneissic cover, in: Proceedings of the 5th International Symposium on Landslides, Lausanne, Switzerland, 10-15 July 1988, vol. 1, edited by: Bonnard, C., 565-570, 1988.

Catani, F., Casagli, N., Ermini, L., Righini, G., and Menduni, G.: Landslide hazard and risk mapping at catchment scale in the Arno River basin, Landslides, 2, 329-342, doi:10.1007/s10346005-0021-0, 2005.

Corominas, J. and Moya, J.: Reconstructing recent landslide activity in relation to rainfall in the Llobregat River basin, Eastern Pyrenees, Spain, Geomorphology, 30, 79-93, available at: http://www.sciencedirect.com/science/article/ B6V93-3YS8JHH-8/2/58792b4a7097ce611f0586788e2c2a9f, 1999.

Corominas, J. and Moya, J.: A review of assessing landslide frequency for hazard zoning purposes, Eng. Geol., 102, 193213, doi:10.1016/j.enggeo.2008.03.018, special issue: Landslide Susceptibility, Hazard and Risk Zoning for Land Use Planning, available at: http://www.sciencedirect.com/science/article/ pii/S0013795208001841, last access: 21 March 2013, 2008.

Crosta, G.: Regionalization of rainfall thresholds: an aid to landslide hazard evaluation, Environ. Geol., 35, 131-145, doi:10.1007/s002540050300, 1998.

Crosta, G. B. and Dal Negro, P.: Observations and modelling of soil slip-debris flow initiation processes in pyroclastic deposits: the Sarno 1998 event, Nat. Hazards Earth Syst. Sci., 3, 53-69, doi:10.5194/nhess-3-53-2003, 2003.

Crosta, G. B. and Frattini, P.: Distributed modelling of shallow landslides triggered by intense rainfall, Nat. Hazards Earth Syst. Sci., 3, 81-93, doi:10.5194/nhess-3-81-2003, 2003.

Crozier, M. J.: Prediction of rainfall-triggered landslides: a test of the Antecedent Water Status Model, Earth Surf. Processes, 24, 825-833, doi:10.1002/(SICI)10969837(199908)24:9<825::AID-ESP14>3.0.CO;2-M, 1999.

Crozier, M. J.: Multiple-occurrence regional landslide events in New Zealand: hazard management issues, Landslides, 2, 247256, doi:10.1007/s10346-005-0019-7, 2005.

Crozier, M. J., Eyles, R. J., Marx, S. L., McConchie, J. A., and Owen, R. C.: Distribution of landslips in the Wairarapa hill country, New Zeal. J. Geol. Geop., 23, 575-586, doi:10.1080/00288306.1980.10424129, 1980.

De Quervain, F. and Frey, D.: Geotechnische Karte der Schweiz 1 : 200 000: Blatt Nr. 2 Luzern-Zürich-St. Gallen-Chur: Erläuterungen, Schweizerischen Geotechnischen Kommission, 2nd edition, 1963 (in German).

De Quervain, F. and Frey, D.: Carte Géotechnique de la Suisse 1 : 200 000: Feuille $n^{0} 3$ Genève-Lausanne-Sion: Texte explicatif, Commission Géotechnique Suisse, 2nd Edn., 1965 (in French and German).
De Quervain, F. and Frey, D.: Carta Geotecnica della Svizzera 1 : 200 000: Foglio $n^{0} 4$ Bellinzona-St. Mortiz: Note esplicative, Commissione Geotecnica Svizzera, 2nd Edn., 1967 (in Italian and German).

De Quervain, F. and Hofmänner, F.: Carte Géotechnique de la Suisse 1: 200 000: Feuille ${ }^{0} 1$ Neuchâtel-Bern-Basel: Texte explicatif, Commission Géotechnique Suisse, 2nd Edn., 1964 (in French and German).

De Vita, P., Reichenbach, P., Bathurst, J. C., Borga, M., Crosta, G., Crozier, M., Glade, T., Guzzetti, F., Hansen, A., and Wasowski, J.: Rainfall-triggered landslides: a reference list, Environ. Geol., 35, 219-233, doi:10.1007/s002540050308, 1998.

D'Odorico, P., Fagherazzi, S., and Rigon, R.: Potential for landsliding: dependence on hyetograph characteristics, J. Geophys. Res.-Earth, 110, nF01007, doi:10.1029/2004JF000127, 2005.

Einstein, H. H.: Special lecture: Landslide risk assessment procedure, in: Proceedings of the 5th International Symposium on Landslides, edited by: Bonnard, C., Lausanne, Switzerland, 2, 1075-1090, 1988.

FOEN: Naturereigniskataster - StorMe, available at: http://www. bafu.admin.ch/naturgefahren/11421/11426/index.html, last update: 21.08.2012, last access: 15.08.2013 (in German).

Foresti, L. and Pozdnoukhov, A.: Exploration of alpine orographic precipitation patterns with radar image processing and clustering techniques, Meteorol. Appl., 19, 407-419, doi:10.1002/met.272, 2012.

Foresti, L., Pozdnoukhov, A., Tuia, D., and Kanevski, M.: Extreme precipitation modelling using geostatistics and machine learning algorithms, in: geoENV VII - Geostatistics for Environmental Applications, Quant. Geol. Geostat. 16, 41-52, 2010.

Foresti, L., Kanevski, M., and Pozdnoukhov, A.: Kernel-based mapping of orographic rainfall enhancement in the Swiss Alps as detected by weather radar, IEEE T. Geosci. Remote, 50, 29542967, 2012.

Gabella, M., Bolliger, M., Germann, U., and Perona, G.: Large sample evaluation of cumulative rainfall amounts in the Alps using a network of three radars, Atmos. Res., 77, 256-268, 2005.

Galli, M. and Guzzetti, F.: Landslide vulnerability criteria: a case study from umbria, central Italy, Environ. Manage., 40, 649-665, doi:10.1007/s00267-006-0325-4, 2007.

Gamma, P.: dfwalk - Ein Murgang-Simulationsprogramm zur Gefahrenzonierung, Ph.D. thesis, University of Bern, Switzerland, 2000 (in German).

Geotest, Geo7 and Oeko-B: SilvaProtect-CH: Schutzwaldhinweiskarte der Schweiz: Modul EVENT (Los 1: Prozess Steinschlag/Blockschlag und Los 2: Prozesse Hangmure/Rutschung, Murgang), Zollikofen, Switzerland, 2006.

Germann, U., Galli, G., Boscacci, M., and Bolliger, M.: Radar precipitation measurement in mountainous region, Q. J. Roy. Meteor. Soc., 132, 1669-1692, 2006.

Germann, U., Berenguer, M., Sempere-Torres, D., and Zappa, M.: REAL - ensemble radar precipitation estimation for hydrology in mountainous region, Q. J. Roy. Meteor. Soc., 135, 445-456, 2009.

Ghosh, S., van Westen, C. J., Carranza, E. J. M., and Jetten, V. G.: Integrating spatial, temporal, and magnitude probabilities for medium-scale landslide risk analysis in Darjeeling Himalayas, India, Landslides, 9, 371-384, doi:10.1007/s10346-011-0304-6, 2012. 
Glade, T.: Establishing the frequency and magnitude of landslidetriggering rainstorm events in New Zealand, Environ. Geol., 35, 160-174, doi:10.1007/s002540050302, 1998.

Glade, T., Crozier, M., and Smith, P.: Applying probability determination to refine landslide-triggering rainfall thresholds using an empirical “Antecedent Daily Rainfall Model”, Pure Appl. Geophys., 157, 1059-1079, doi:10.1007/s000240050017, 2000.

Godt, J., Baum, R., Savage, W., Salciarini, D., Schulz, W., and Harp, E.: Transient deterministic shallow landslide modeling: Requirements for susceptibility and hazard assessments in a GIS framework, Eng. Geol., 102, 214-226, doi:10.1016/j.enggeo.2008.03.019, 2008.

Greco, R., Giorgio, M., Capparelli, G., and Versace, P.: Early warning of rainfall-induced landslides based on empirical mobility function predictor, Eng. Geol., 153, 67-79, doi:10.1016/j.enggeo.2012.11.009, 2013.

Gullà, G., Antronico, L., Iaquinta, P., and Terranova, O.: Susceptibility and triggering scenarios at a regional scale for shallow landslides, Geomorphology, 99, 39-58, doi:10.1016/j.geomorph.2007.10.005, 2008.

Guzzetti, F., Peruccacci, S., Rossi, M., and Stark, C.: The rainfall intensity-duration control of shallow landslides and debris flows: an update, Landslides, 5, 3-17, doi:10.1007/s10346-007-0112-1, 2008.

Hilker, N., Aller, D., and Hegg, C.: Ereignisanalyse Hochwasser 2005: Teil 1 - Prozesse, Schäden und erste Einordnung, chap. Schäden, Bundesamt für Umwelt BAFU, edited by: Bezzola, G. R. and Hegg, C., Eidg. Forschungsanstalt WSL, Bern and Birmensdorf, Switzerland, 127-148, 2007 (in German).

Hilker, N., Badoux, A., and Hegg, C.: The Swiss flood and landslide damage database 1972-2007, Nat. Hazards Earth Syst. Sci., 9, 913-925, doi:10.5194/nhess-9-913-2009, 2009.

Iida, T.: A stochastic hydro-geomorphological model for shallow landsliding due to rainstorm, Catena, 34, 293-313, available at: http://www.sciencedirect.com/science/article/ B6VCG-3VTYVWW-5/1/272affa188fa14bbfd4d7290700da4c3 (last access: 21 March 2013), 1999.

Iida, T.: Theoretical research on the relationship between return period of rainfall and shallow landslides, Hydrol. Process., 18, 739756, doi:10.1002/hyp.1264, 2004.

Jaboyedoff, M. and Bonnard, C.: Report on landslide impacts and practices in Switzerland: Need for new risk assessment strategies, in: The 2007 International Forum on Landslide Disaster Management, edited by: Ho, K. and Li, V., Geotechnical Division, The Hong Kong Institution of Engineers, Hong Kong, 7997, 2007.

Jaiswal, P., van Westen, C. J., and Jetten, V.: Quantitative estimation of landslide risk from rapid debris slides on natural slopes in the Nilgiri hills, India, Nat. Hazards Earth Syst. Sci., 11, 1723-1743, doi:10.5194/nhess-11-1723-2011, 2011.

Johnson, N. L., and Kotz, S.: Continuous univariate distributions-1, John Wiley \& Sons, 1970.

Kanevski, M., Pozdnoukhov, A., and Timonin, V.: Machine Learning for Spatial Environmental Data: Theory, Applications and Software, EPFL Press, Lausanne, Switzerland, 2009.

Kaplan, S.: The Words of Risk Analysis, Risk Anal, 17, 407-417, doi:10.1111/j.1539-6924.1997.tb00881.x, 1997.

Liener, S., Kienholz, H., Liniger, M., and Krummenacher, B.: SLIDISP - A procedure to locate landslide prone areas, in: Land- slides - Glissements de terrain, Proceedings of the seventh international symposium on landslides, 17-21 June 1996, Trondheim, Norway, edited by: Senneset, K., Balkema, Rotterdam, 1996.

Mathai, A. M.: An Introduction to Geometrical Probability: Distributional Aspects with Applications, Gordon and Breach, Newark, USA, 1999.

Matsushi, Y. and Matsukura, Y.: Rainfall thresholds for shallow landsliding derived from pressure-head monitoring: cases with permeable and impermeable bedrocks in Boso Peninsula, Japan, Earth Surf. Processes, 32, 1308-1322, doi:10.1002/esp.1491, 2007.

Merz, B., Kreibich, H., Thieken, A., and Schmidtke, R.: Estimation uncertainty of direct monetary flood damage to buildings, Nat. Hazards Earth Syst. Sci., 4, 153-163, doi:10.5194/nhess-4-1532004, 2004.

Michoud, C., Derron, M.-H., Jaboyedoff, M., Nadim, F., and Leroi, E.: Classification of landslide-inducing anthropogenic activities, in: 5th Canadian Conference on Geotechnique and Natural Hazards, 15-17 May 2011, Kelowna, BC, Canada, 10 pp., 2011.

Montgomery, D. and Dietrich, W.: A physically based model for the topographic control on shallow landsliding, Water Resour. Res., 30, 1153-1171, 1994.

Mueller, R. and Loew, S.: Predisposition and cause of the catastrophic landslides of August 2005 in Brienz (Switzerland), Swiss J. Geosci., 102, 331-344, doi:10.1007/s00015-009-13153, 2009.

Nguyen, H., Wiatr, T., Fernández-Steeger, T., Reicherter, K., Rodrigues, D., and Azzam, R.: Landslide hazard and cascading effects following the extreme rainfall event on Madeira Island (February 2010), Nat. Hazards, 65, 635-652, 2013.

Pack, R., Tarboton, D. G., and Goodwin, C. N.: The SINMAP approach to terrain stability mapping, in: 8th Congress of the International Association of Engineering Geology, 21-25 September 1998, Vancouver, British Columbia, Canada, 8 pp., 1998.

Preuth, T., Glade, T., and Demoulin, A.: Stability analysis of a human-influenced landslide in eastern Belgium, Geomorphology, 120, 38-47, doi:10.1016/j.geomorph.2009.09.013, 2010.

Raetzo, H. and Rickli, C.: Ereignisanalyse Hochwasser 2005: Teil 1 - Prozesse, Schäden und erste Einordnung, chap. Rutschungen, edited by: Bezzola, G. R. and Hegg, C., Bundesamt für Umwelt BAFU, Eidg. Forschungsanstalt WSL, Bern and Birmensdorf, Switzerland, 195-210, 2007 (in German).

Remondo, J., Bonachea, J., and Cendrero, A.: A statistical approach to landslide risk modelling at basin scale: from landslide susceptibility to quantitative risk assessment, Landslides, 2, 321-328, doi:10.1007/s10346-005-0016-x, 2005.

Rickli, C., Raetzo, H., McArdell, B., and Presler, J.: Ereignisanalyse Hochwasser 2005: Teil 2 - Analyse von Prozessen, Massnahmen und Gefahrengrundlagen, chap. Hanginstabilitäten, edited by: Bezzola, G. R. and Hegg, C., Bundesamt für Umwelt BAFU, Eidg. Forschungsanstalt WSL, Bern and Birmensdorf, Switzerland, 97-116, 2008 (in German).

Ross, S. M.: A first course in probability, 8th Edn., Pearson Education, Upper Saddle River, USA, 2010.

Rotach, M., Appenzeller, C., and Albisser, P. E.: Starkniederschlagsereignis August 2005, Arbeitsberichte 211, MeteoSchweiz, Zürich, Switzerland, 2006 (in German). 
Seed, A. W., Srikanthan, R., and Menabde, M.: A space and time model for design storm rainfall, J. Geophys. Res.-Atmos., 104, 31623-31630, doi:10.1029/1999JD900767, 1999.

SGTK: Datenbeschreibung der geotechnischen, lithologischpetrographischen Polygone, Schweizerische Geotechnische Kommission, Zürich, Switzerland, 2012 (in German).

Sideris, I. V., Gabella, M., Erdin, R., and Germann, U.: Real-time radar-raingauge merging using spatiotemporal co-kriging with external drift in the alpine terrain of Switzerland, Q. J. Roy. Meteor. Soc., doi10.1002/qj.2188, in press, 2013.

Tarolli, P., Borga, M., Chang, K.-T., and Chiang, S.-H.: Modeling shallow landsliding susceptibility by incorporating heavy rainfall statistical properties, Geomorphology, 133, 199-211, doi:10.1016/j.geomorph.2011.02.033, 2011.

Taylor, F. E., Santangelo, M., Marchesini, I. and Malamud,B. D.: A GRASS GIS Semi-Stochastic Model for Evaluating the Probability of Landslides Impacting Road Networks in Collazzone, Central Italy, Abstr., EGU2013-7624, EGU General Assembly 2013, Vienna, Austria, 2013.

Trümpy, R.: Geology of Switzerland, Part A: An outline of the Geology of Switzerland, Wepf \& Co. Verlag, Basel, Switzerland, 1980.

University of Bern and FOWG: Geological Map of Switzerland $1: 500000$, Swisstopo, Bern, Switzerland, ISBN 3-906723-39$9,2005 \mathrm{a}$.

University of Bern and FOWG: Tectonic Map of Switzerland 1 : 500 000, Swisstopo, Bern, Switzerland, ISBN 3-906723-56-9, 2005b.

Valley, B., Thuro, K., Eberhardt, E., and Raetzo, H.: Geological and geotechnical investigation of a shallow translational slide along a weathered rock/soil contact for the purpose of model development and hazard assessment, in: Proceedings of the 9th International Symposium on Landslides, Rio de Janeiro, 28 June-2 July 2004, edited by: Lacerda, W. A., Ehrlich, M., Fontoura, S. A. B., and Sayão, A. S. F., A. A. Balkema, 385-391, 2004. van Westen, C., van Asch, T., and Soeters, R.: Landslide hazard and risk zonation - why is it still so difficult?, B. Eng. Geol. Environ., 65, 167-184, doi:10.1007/s10064-005-0023-0, 2006.

von Ruette, J., Papritz, A., Lehmann, P., Rickli, C., and Or, D.: Spatial statistical modeling of shallow landslides - validating predictions for different landslide inventories and rainfall events, Geomorphology, 133, 11-22, doi:10.1016/j.geomorph.2011.06.010, 2011.

Weisstein, E. W.: Clean Tile Problem, MathWorld - A Wolfram Web Resource, available at: http://mathworld.wolfram. com/CleanTileProblem.html (last access: 15 August 2013), 2013.

Whittaker, K. A. and McShane, D.: Comparison of slope instability screening tools following a large storm event and application to forest management and policy, Geomorphology, 145-146, 115122, doi:10.1016/j.geomorph.2012.01.001, 2012.

Wieczorek, G. F.: Landslide triggering mechanisms, in: Landslides Investigation and Mitigation, edited by: Turner, A. K. and Schuster, R. L., Special Report 247, Transportation Research Board, National Research Council, National Academy Press, Washington, DC, 76-90, 1996.

WSL: Swiss flood and landslide damage database, available at: http://www.wsl.ch/fe/gebirgshydrologie/HEX/projekte/ schadendatenbank/index_EN (last access: 26 February 2013), 2012.

Wüest, M., Frei, C., Altenhoff, A., Hagen, M., Litschi, M., and Schär, C.: A gridded hourly precipitation dataset for Switzerland using rain-gauge analysis and radar-based disaggregation, Int. J. Climatol., 30, 1764-1775, 2010.

Yu, F.-C., Chen, T.-C., Lin, M.-L., Chen, C.-Y., and Yu, W.-H.: Landslides and rainfall characteristics analysis in Taipei City during the Typhoon Nari event, Nat. Hazards, 37, 153-167, doi:10.1007/s11069-005-4661-0, 2006. 